\title{
Negative constructions with "нет" (nо) influencing the choice of the genitive form of nouns
}

\author{
Lydia Ogorodnikova ${ }^{1, *}$ and Yulia Ryndina ${ }^{1}$ \\ ${ }^{1}$ Ishim Ershov Teachers Training Institute (branch) of the University of Tyumen, 1, Lenin str., 627755, Ishim, Russia,
}

\begin{abstract}
The article presents a further study of the genitive case variant inflection distribution in inanimate masculine nouns, found in fiction and journalistic texts of the second half of the 18th century. The focus is on the double negation in impersonal-predicative constructions with the word "no". The relevance of the study is due to the persistent ambiguity of the choice of the genitive case form of words. The novelty is due to the literary sources created during the norm-establishing phase of the Russian literary language development. The article describes forms of the genitive case that have existed in the Russian language for a long time. The authors interpret the mechanism for choosing the genitive case by the authors of fiction and journalistic texts. The authors argue that a negative construct as a syntactic factor has little effect on the choice of the genitive case. The article discusses results of the comparative analysis of noun forms with $\mathrm{A}$ - and $\mathrm{Y}$-endings. In all types of negative constructions, the A-ending predominates, whereas the $\mathrm{Y}$-ending is observed in adverbial constructions and emphatic negations. A classification of structural types of negative sentences with genitive forms was developed.
\end{abstract}

\section{Introduction}

This article is part of a series of works devoted to variant forms of the genitive case of inanimate masculine nouns used in the works of Russian writers of the second half of the 18th century (fiction and journalistic genres) [1, 2]).

Factors affecting the choice of an ending can be combined into several groups: lexical, structural, accentological, and syntactic.

The article is devoted to the role of one of the syntactic factors, namely: negative constructions with the lexeme нет, constructions with a double negation and impersonal-predicative words.

XVIII century is the period of Europeanization of the Russian literary language "deep into the grammatical and semantic system" [3], rapprochement of the literary language and colloquial speech.

The article studies fiction and journalistic texts of the second half of the 18th century: the poem "The Great Peter" by M.V. Lomonosov, comedies by M.I. Popov, M.I. Verevkin, V.V. Kapnist, sentimental novels by N.M. Karamzin, "Anacreontic songs" by G.R. Derzhavin, "A Journey from St. Petersburg to Moscow" by A.N. Radishchev, articles by N.I. Novikov. An analysis of the language material allowed us to draw reliable conclusions about the distribution of genitive inflections in negative constructions with the word $\mathrm{Hem}$, a double negation, impersonal-predicative words. The authors preserved the original spelling.

\section{Literature review}

The category of negation has long attracted attention of linguists. Its logical-linguistic aspect is considered by E.S. Shternina who claims that there is "no consensus on the status of negative constructions, depending on the means of expressing negation" [4]. The article discusses classifications of Russian negative sentences developed by various scholars.

The development of the Russian genitive case dates back several centuries. In 1696, G. Ludolph wrote about the Russian genitive case as one of negative constructions: "The genitive case is used instead of the nominative one after неть, for example, нету таково человЂка, которои все знаеть... [5].

P.S. Kuznetsov emphasizes the genetic connection of the genitive case in negation with the partitive meaning (a part of the whole): $и$ часу не прошло, он и годуне просидел, без году неделя, ни шагу назад. In constructions with negation, such nouns mean a part that is singled out from the whole. "In the Russian language, there is a general grammatical category uniting the name and the verb. The semantics of this category is determined by the relation of the part and the whole. The category of partivism characterizes the Russian language development: it is absent in Church Slavonic, and its use in the literary language is limited "[6].

The article by E.V. Paducheva "The Genetics of an object in Negative Sentences" [7] emphasizes the semantic motivation of the genitive case.

\footnotetext{
* Corresponding author: melodica@yandex.ru
} 
In the Russian language, the means of expressing negation is a sentence and units of other levels: negative prefixes, prepositions, particles, pronouns, and adverbs.

Negation can be expressed in idiomatic and intonation.

E.V. Loktev studies impersonal negative constructions, in which the genitive is an integral part. The basis for highlighting the structural types of negative genitive sentences is a means of expressing the negative component [8]. The semantic classification of negative genitive sentences is represented by four types of constructions: expressing the significance of the state of the environment; the physical condition of the subject; the mental, emotional state; impersonal modal semantics [8].

The term double negation syntactic constructions is used to refer to sentences in which "there are several negative elements" [4]. This kind of sentences is present in other languages, for example, in English. In his work "Means for expressing negation in English", $\mathrm{H}$. Hankamer writes: "Double negation is expressed by means of different language levels (morphological, lexical, syntactic) and serves to express an unintensified statement, a positive non-categorical statement (litota) or a categorical, underlined statement" [9].

Interesting materials on double negation in the Russian and Persian languages are presented in the article by Hosseini A. and Ganbari-Erdi F. S. Who compare the use of means of expressing different shades of meaning in affirmative and negative syntactic constructions [10].

In the article "Excessive and Variant Case Forms in the Modern Russian Language", L.N. Desheulina deals with genitive forms with A-and $\mathrm{Y}$-endings. The author predicts a gradual reduction in the use of $\mathrm{Y}$-forms and their displacement by A-forms [11].

A.I. Plotnikova argues that the choice of the ending of the genitive case determines the interconnection of syntactic and semantic criteria [12].

Thus, the development of negative constructions, genitive forms as part of such constructions and constructions of other types has been carried out for many years. The problem of choosing the genitive form in negative constructions is analyzed in the works by many scientists ; however, these forms used in Russian literature of the XVIII century are understudied.

\section{Distribution of genitive inflections in sentences with a negative word нет}

Negation, being one of the fundamental categories of language, is a category peculiar to all languages of the world.

In the history the Slavic languages, including Russian, had widespread forms of genitive on $-\mathrm{Y}$. The Proto-Slavic language inherited the form and the productive model.

The word "no" in the negative propositions implies the meaning of the negation of existence.

The $\mathrm{Y}$-ending in the genitive form with a negative word нет is not used in material and abstract substantives «долгу на мне нет ни полушки» [13], «в обеих нет мозгу» [13]. The lexeme пример does not belong to the lexical and grammatical categories: «B тебе, Россия, нет примеру» [14]. The material noun мел in such syntactic constructions is used with -A: «наличного нет мела» [15]. The mobile vowel based on a specific stem of the lexeme сучок is a favorable factor for choosing the A-ending: «нет на них такого гнилого сучка» [16]. The У-form is stylistically reduced.

The forms of abstract nouns, even in colloquial sentences are used only with -А: «да голоса-то нету» [15], «здесь персть твоя, а духа нет» [17], «нет такого закона» [16], «ни день, ни ночь покоя нету» [17], «етого порока нет» [18], «другога промысла нет» [18], «В этом нет спора» [18].

The negative word нет is often accompanied by negative particles. In this case, -A remains dominant both names of inanimate objects and nouns denoting abstract concepts: «в том ни греха, ни стыда нет» [17], «нет во всём доме ни лоскутка бумаги» [17], «ни разума в нём нет, ни склада» [18]. «Где нет ни правил, ни закону» [14] - in this combination, the Уform is used as stylistically marked in the poem by M.V. Lomonosov "Peter the Great."

\section{Distribution of genitive inflections in double negation sentences}

The presence of two negative particles is a Slavic neoplasm. It is found in the old Russian and Church Slavonic texts. For example, in the Ostromir gospel: и никъто же не Ааवше юмог; мън'

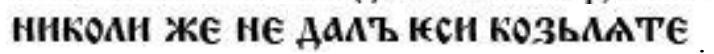

(Nobody gave him anything; they did not give me those goats).

In English, double negation is virtually nonexistent, except for the cases when the negative element follows the negative particle nor at the beginning of a sentence. Until the 18th century, in British English, two means of negation were used in the same sentence to create emphasis (e.g. Shakespeare's Twelfth Night). However, around the time of a decree that two negatives should equal a positive, English negative concord had already begun to undergo a process of social stigmatization. The socially motivated shift away from negative concord involved the diachronic replacement of negative constituents like nothing with negative polarity items like anything.

Shakespeare's Twelfth Night uses a triple-negative in the following line: "And that no woman has nor never none Shall mistress of it be, save I alone" [9]. Chaucer makes use of double negatives to describe characters, such as the Friar, in The Canterbury Tales: "There never was no man nowhere so virtuous" [9].

Double negation is now considered as a phenomenon that does not correspond to standard British English. Despite the prohibition of double negation, there are cases of its use in modern colloquial discourse and some dialects. For example, "He didn't do nothing 
wrong" [9]. In this combination, did not (the negative particle before the verb) and the negative pronoun nothing serve to reinforce the negative meaning.

In cases of negative concord involving a negative subject, the concordant negative subject precedes the negative marker "not".

In any given discourse context, the negative words or constituents like nobody and nothing in Negative Concord sentences are interchangeable with words like anybody and anything, which contain no overt negative morpheme.

English sentences with two negatives may have a negative and not an affirmative meaning. However, sometimes two negatives do yield an affirmative.

Grammars of the 18th century tried to explain the infidelity of the use of double negation in language from the standpoint of logical construction of judgment: two negations neutralize each other, and the result is a positive value. If this does not happen and several negative elements express a negative value, one element should be sufficient.

Double negation constructions contain transitional verbs with a particle $\mu e$ which manage nouns denoting an object that cannot be divided into parts. The particle $н и$ intensifies negation: вкус - «в его, де, сатирах, ни соли, ни вкуса не находят» [17], кусок - «не евщи ни куска» [15], момент - «не тратя ни момента» [15], палец - «не гну и пальца даром» [15], пул - «в мошне не было ни пула» [17], холст - «ни холста ... не уступит» [19], иеляг - «ни иеляга не дам» [15]. In these forms, $-\mathrm{A}$ is dominant. The proper use of genitive forms in double-negation constructions means using the A-form: «недостойных ни чина, ни имени» [17], «он и пальца ея не достоин» [18]. Among the examples, there are lexemes of foreign origin: nул (the name of a copper coin), шеляг (the name of a foreign coin), момент. The word вкус meaning "a sense of grace" was borrowed from French at the end of the 18th century.

According to the observations by V.A. Bogoroditsky, with the introduction of a negative particle, "negation takes on a more decisive character" [20]: «ни гласу, ни послушания» [13], «чтоб не было и духу его у нас в дому» [15], «во всём доме таки ни духу хозяйскаго» [13]. Colloquial combinations and adverbs have similar meanings. $-\mathrm{Y}$ is basic, "the most common" [20], but -A can be used as well. Forms with irregular endings are found in utterances pronounced by comedy heroes: «нет ни духа» [15], «не видав меня ещё ни раза в жизни, осмелился ... выболтнуть любовное своё объявление» [18].

In sentences with no negation, some lexemes (глас, дух, чин) do not mean a part isolated from the whole. This meaning can be derived only if there is a negation.

A coherent definition expressed by a negative pronoun can intensify the negation. The A-form is used in the following constructions: «никакого вреда не причинит» [17], «не предъявя к тому предлога никакова» [15]. In sentences of the comedy character, there is a $\mathrm{Y}$-form: «не видывал я ни в чём и никакова у нево недостатку» [13]. Negation is enhanced by the presence of an object - a negative pronoun in the prepositional case. For example, in some sources, the genitive form of the lexeme недостаток is accompanied by a negative pronoun: «не имели ни в чём недостатка» [21], «ни в чём не имели недостатка» [16].

The $-\mathrm{y}$ form is not used in the construction with $\mu u$. It is used with abstract nouns: «ни caxapy $\boldsymbol{\mu}$ покупаешь» [19]. The negative adverb accompanying the genitive case ending with -A («ни где примера не находим» [19]) intensifies the negation.

\section{Genitive forms in sentences with impersonal predicative words}

Among one-part sentences, impersonal sentences are the most common and common types. The peculiarity of the proposals under consideration is the presence of a combination of a negative word with a genitive form in their structures. The elimination of negation makes these sentences personal. The basic semantics of sentences with a genitive form is the denial of the presence of objects, phenomena, signs, their absence.

In impersonal negative constructions, the genitive form ending with $\mathrm{Y}$ - of the colloquial noun заквас is used (meaning "the basis of something") with lexemes meaning the indivisible whole начёm and оклад: «заквасу в нём не будет» [19], «начёту на мне не было» [19], «на полтора рубля окладу не наберётся» [17]. Material nouns end with -A: «не вышло листочка» [17], «нельзя будет испечь пирога» [17] in impersonal negative constructions. Abstarct nouns end with -A in these constructions: брак - «там и брака быть не может» [19], вред - «не может быть вреда» [19], ответ - «мне ни полстрочкою ответа не дано» [15], покров - «не будет тебе покрова от угнетения» [19], смысл - «не достанет на ето смысла»; спор - «и спора не явилось» [15], труд «уговорить меня труда не стоит» [15], удар - «не снести тебе едакова удара » [13].

\section{Varieties of impersonal negative genitive constructions according to the means of expressing negative
components}

In accordance with this criterion, there are the following structural varieties of negative genitive constructions:

- нет included in the paradigm of the negative verb быль [8, р. 76]: «заквасу в нём не будет» [Радищев], «начёту на мне не было» [19], «не будет тебе покрова от угнетения» [19], «чтоб не было и духу его у нас в дому» [15], «в том ни греха, ни стыда нет» [17];

- negative collocations: где нет ни правил, ни закону [14];

- impersonal forms of negative verbs expressing appearance, occurrence, disappearance, change $[8, \mathrm{p}$. 76]: «я чаю, не достанет на ето смысла», «и спора не явилось» [15], «там и брака быть не может» 
[19], «не может быть вреда» [19], «уговорить меня труда не стоит» [15]; «не вышло листочка» [17];

- impersonal forms of negative short passive participles: мне ни полстрочкою ответа не дано [15];

- impersonal predicates meaning sufficiency: «я чаю, не достанет на ето смысла» [15], «на полтора рубля окладу не наберётся» [17].

Thus, five types of negative sentences with genitive form are presented in our materials. Some of them contain negation as a necessary component (in sentences with the word "no") ; others are negative in the nature of the information (sentences in which the negative particle is not the main term expressing the predicative trait).

\section{Conclusion}

Thus, the choice of the genitive form in negative constructions determines the belonging of a noun to a certain lexical and grammatical category. Material lexemes require the use of $-\mathrm{y}$. Double negation syntactic constructions with negative particles, secondary parts expressed with negative pronouns and negative adverbs do not infleunce the genitive form. The $\mathrm{Y}$-form is dominnt in nouns meaning an adverb in combination with a negative particle. The specific meaning of substantives in negative constructions determines the use of the A-form. Colloquial lexemes have the A-ending in negative constructions.

Observations allow us to state that the majority of constructions containing genitive forms are part of impersonal genitive sentences of various structural types: with нет included in the paradigm of the verb бolmb; phraseological units meaning negation; impersonal forms of verbs meaning appearance, occurrence, disappearance, change with a negation; impersonal forms of short passive participles with a negation; impersonal predicates meaning prosperity and completeness.

So, our research touched upon one of the aspects of the category of negation in the Russian language. One of the special questions is considered - means of expression of this category, grammatical forms as a part of negative constructions. Our materials can be used to develop courses in the history of the Russian literary language, stylistics, as well as by teaching Russian to foreign students.

\section{References}

1. L.A. Ogorodnikova, Tomsk State University Bulletin Nominal and verbal constructions of the genitive case in the works by writers and publicists of the second half of the 18th century, 369, 33-37 (2013)
2. L.A. Ogorodnikova, Contemporary science: actual problems of theory and practice. Ser. Humanitarian sciences The paradigm of the genitive case in negative constructions with transitive and intransitive verbs (based on fiction and journalistic texts of the second half of the 18th century), 5, 146-148 (2018)

3. V.V. Vinogradov, Essays on the History of Russian Literary Language of the 17th - 19th Centuries (1982)

4. E.S. Shternina, Category of negation: logicallinguistic aspect, Philology. Questions of theory and practice 9 (15), 2, 211-214 (2015)

5. G.V. Ludolph, Russian Grammar 89. (1937)

6. P.S. Kuznetsov, Essays on the morphology of the PreSlavic language, 150. (1961)

7. E.V. Paducheva, Questions of linguistics, Genetive of the objective compelement in a negative sentence, 6,21 43 (2006)

8. E.V. Loktev, Bulletin of Cherepovets State University. Ser. Philological sciences, Negative genitive sentences in modern Russian, 4, 2, 76-78 (2013)

9. Jorge Hankamer, Auxiliaries and Negation in English. 6 (2011)

10. A. Hosseini, F.S. Ganbari-Erdi, Young scientist, Double negation in Russian and Persian, 3, 983-987 (2015)

11. L. N. Desheulina, Proceedings of RAS, Excessive and Variant Case Nouns in Modern Russian, VI, 2, 322340 (2010).

12. A. I. Plotnikova, Moscow University Herald. Ser. 9. Philology, Choice of the genitive ending for singular masculine nouns in the history of the Russian language, 6, 134-145 (2015)

13. M.I. Veryovkin, Birthday man, (1774).

14. M.V. Lomonosov, Selected Works, (1986).

15. V.V. Kapnist, Collected Works, 1, (1960).

16. G.R.Derzhavin, A.D. Galakhov, Selected works, Historical and literary anthology of the new period of Russian literature, (1898).

17. N.I. Novikov, Novikov and his contemporaries, Selected Works, (1961).

18. M. Popov, Leisure or collected works, St. Petersburg, (1772).

19. A.N. Radishchev, Complete collection of Works, 1, (1938).

20. V.A. Bogoroditsky, Essays on Linguistics and the Russian Language, 228, (2019).

21. N.M. Karamzin, Letters of the Russian traveler, (1986), 